\section{Resistance to Geminivirus Mixed Infections in Mexican Wild Peppers}

\author{
J.L. Anaya-López ${ }^{1}$, I. Torres-Pacheco ${ }^{2}$, M. González-Chavira ${ }^{3}$, \\ J.A. Garzon-Tiznado ${ }^{4}$, and J.L Pons-Hernandez ${ }^{3}$ \\ Unidad de Biotecnología del Bajío, Instituto Nacional de Investigaciones \\ Forestales Agrícolas y Pecuarias-Campo Experimental Bajío., Apartado \\ postal 112, Celaya, Gto, México
}

\section{R.G. Guevara-González ${ }^{4}$, C.I. Muñoz-Sánchez ${ }^{4}$, and}

L. Guevara-Olvera ${ }^{4}$

Departamento de Ingeniería Bioquímica, Instituto Tecnológico de Celaya, Apartado postal 57, Celaya, Gto, México

\section{R.F. Rivera-Bustamante ${ }^{4}$ \\ Departamento de Ingeniería Genética, Centro de Investigación y de Estudios Avanzados del IPN Unidad Irapuato, Apartado postal 629, Irapuato, Gto, México}

\section{S. Hernández-Verdugo ${ }^{3}$ \\ Facultad de Agronomía, Universidad Autónoma de Sinaloa; Código postal 80000, Culiacán, Sinaloa, México}

Additional index words. virus movement, biolistic, grafting, Capsicum sp.

\begin{abstract}
Screening for resistance to mixed infections with pepper huasteco virus (PHV) and pepper golden mosaic virus (PepGMV) was carried out on plants representing wild pepper accessions collected in different states of México. One accession collected in Yucatán (BG-3821) corresponded to Capsicum chinense Jacq., and three collected from Michoacán (BG-3818), Tamaulipas (BG-3820), and Sinaloa (BG-3819) were identified as $C$. annuum $\mathrm{L}$. Forty-eight plants were initially inoculated with a $1: 1 \mathrm{mix}$ of PHV and PepGMV DNAs by a biolistic method. Those plants that did not show typical symptoms after the biolistic method, were inoculated by grafting. Half of the plants (24) were highly susceptible, while the other half expressed different degrees of resistance. Of the resistant individuals, eight plants were asymptomatic and viral DNA of both viruses was detected in low levels. Two individuals showed delayed symptoms 34 days after symptom expression in the control plants. This delay was correlated with an increase in PHV DNA levels when plants became symptomatic. The remaining 14 plants showed symptom remission in newly developed leaves at $\mathbf{3 1}$ days postinoculation, and this asymptomatic effect was correlated diminished PHV DNA within the plants. Our results suggest that the resistance shown by some individuals to geminivirus mixed infections (PHV and PepGMV) is likely due to constrains in viral movement.
\end{abstract}

Pepper (Capsicum sp.) has been cultivated in México since prehispanic times; evidence reveals that Capsicum annuum $\mathrm{L}$. and $C$.

Received for publication 19 June 2002. Accepted for publication 17 Sept. 2002. This research was supported by a grant from Sistema de Investigación Miguel Hidalgo (1998-0201018 and 1998-020-1014), CONCyTEG (98-09-01-049 and 01-09-201-088), International Foundation for Science (AC/11325) and CONACyT- México (K325P9702 and J31638-B) to I. Torres-Pacheco and R.G Guevara-González, and CONACyT-México (31866-B) to S. Hernández-Verdugo. J.L AnayaLópez also acknowledges fellowship support from COSNET and International Foundation for Science (AC/11325). We also acknowledge Rita MirandaLópez for critical review of the manuscript.

${ }^{1}$ Graduate Student (Instituto Tecnológico de Celaya).

${ }^{2}$ Plant Virologist. To whom reprint requests should be addressed. E-mail address: itorresp@ hotmail.com

${ }^{3}$ Plant Breeder.

${ }^{4}$ Plant Pathologist.

HortScience, Vol. 38(2), April 2003
1999; Lazarowitz, 1992). The Geminiviridae consists of three different genus: Mastrevirus, Curtovirus, and Begomovirus, with each name representing the type member of the respective genus (maize streak virus, beet curly top virus, and bean golden mosaic virus, respectively) (Hanley-Bowdoin et al., 1999). Seventeen geminiviruses have been reported in the western hemisphere, and five of these have been detected in México (Polston and Anderson, 1997; Torres-Pacheco et al., 1996). Two bipartite, whitefly-transmitted geminiviruses belonging to genus Begomovirus, are commonly detected in mixed infections affecting pepper and tomato (Lycoperscion esculentum Mill.) crops in México (Garzón-Tiznado et al., 1993; Torres-Pacheco et al., 1993, 1996; Vera-Aguado et al., 1999). These viruses are pepper huasteco virus (PHV) and pepper golden mosaic virus (PepGMV, formerly named as Texas pepper virus).

It is important that sources of resistance to these viruses be identified. The wild relatives of plants are an excellent source of resistance genes and interesting agronomic characteristics (Burdon and Jarosz, 1989; Harlan, 1976; Hernández-Verdugo et al; 1998, 2001; Stalker, 1980; Williams, 1988). Several efforts have been carried out to identify resistance to single infections of geminiviruses in wild or cultivated tomato (Kasrawi et al., 1988; Pilowsky and Cohen, 1990; Piven and Uzcategui, 1995; Zakay et al., 1991) and pepper plants (Godínez-Hernández et al., 2001; Hernández-Verdugo et al., 2001), but there are no reports of efforts to identify plants with resistance to mixed infections of these viruses. The identification and characterization of resistance in pepper to mixed infections caused by PHV and PepGMV, may lead to an important advance for Mexican horticulture. Moreover, these materials may serve to study the genetics of resistance and molecular biology with future biotechnological applications.

In this work, 48 individual pepper plants derived from four accessions collected in four different states of México were evaluated for resistance to mixed infections with PHV and PepGMV. Some aspects of the possible resistance mechanism detected in several individuals are discussed.

\section{Materials and Methods} Agriculture Organization (FAO), 1999], and several species are cultivated, including $C$. annuum, $C$. chinense Jacq., $C$. frutescens, $C$. pendulum (Wild.), and C. pubescens R.\&P Capsicum annuum is the most economically important and widely distributed species throughout the country (Pickersgill, 1984; Pozo-Campodónico et al., 1991). Mexican pepper crops typically suffer losses of between $20 \%$ and $100 \%$, due mainly to several viral diseases. Many of the most important diseases are caused by geminiviruses (Garzón-Tiznado et al., 1989; Godínez-Hernández et al., 2001; Torres-Pacheco et al., 1996). Plant viruses in the family Geminiviridae have geminate particle morphology, a DNA genomic organization of either monopartite or bipartite and transmission in nature by treehoppers, leafhoppers, or whiteflies (Hanley-Bowdoin et al.,
Plant material. The study consisted of 48 individual pepper plants representing four accessions of wild pepper collected in the Mexican states of Michoacán (accession BG-3818), Sinaloa (accession BG-3819), Tamaulipas (accession BG-3820), and Yucatán (accession BG-3821, formerly named UX SMH-1; Godínez-Hernández et al., 2001). The plants were produced by harvesting fruits from plants of at least 3 months old and planting the seed in pots $(10 \mathrm{~cm}$ tall $\times 10 \mathrm{~cm}$ diameter) placed in a greenhouse. Seventeen plants Sinaloa, and Tamaulipas). The remaining 31 were of the species $C$. chinense, and were collected in Yucatán. Cultivar Sonora Anaheim was used as an experimental control based on were C. annuum (accessions from Michoacán, 
its high susceptibility to mixed infections of both PHV and PepGMV (Godínez-Hernández et al., 2001; Torres-Pacheco, 1997). This research was conducted on the individual plants and not the original accession. To corroborate the virus-free state of the plants used in our experiments, serological tests (ELISA kit detection; Agdia, Elkhart, Ind.) were conducted to detect viruses commonly found in Mexican pepper crops [tobacco mosaic virus, tobacco etch virus, and cucumber mosaic virus (VeraAguado et al., 1999)]. All the accessions used in this work are available from Instituto $\mathrm{Na}$ cional de Investigaciones Forestales, Agrícolas y Pecuarias (INIFAP), (Campo Experimental Bajío, carretera Celaya-San Miguel de Allende Km 6.5, Apartado Postal 112, Código Postal 38000, Celaya, Guanajuato, México).

Virus inoculation. Inoculation of both PHV and PepGMV (Tamaulipas strain; Torres-Pacheco et al., 1996) DNAs was carried out using a biolistic procedure with a particle delivery system (model PDS 1000; Dupont, Wilmington, Del.). PHV and PepGMV genomes used in this work were originally isolated and cloned from infected pepper plants collected in Tamaulipas (Garzón-Tiznado et al., 1989, 1993). Before bombardments, PHV components $\mathrm{A}$ and $\mathrm{B}$, and component $\mathrm{B}$ of PepGMV were excised from bluescript plasmid using HindIII. Component A of PepGMV was excised from the plasmid with enzyme EcoRI in order to increase the percentage of plants infected using the biolistic procedure (BonillaRamírez et al., 1997). Bombardments used 5 $\mu \mathrm{g}$ of DNA from PHV and PepGMV $(2.5 \mathrm{mg}$ of genomic components A and B from each virus), this inoculum was divided up among six plants. These DNAsamples were deposited on the surface of $3 \mathrm{mg}$ of tungsten microparticles (Tungsten M-10; BIO-RAD, Hercules, Calif.). Bombardment conditions used a gap distance of $1.2 \mathrm{~cm}$ and $56.4 \mathrm{~kg} \cdot \mathrm{cm}^{-2}$ of pressure for each plant (Garzón-Tiznado et al., 1993; Godínez-Hernández et al., 2001). Plants were inoculated at the apical zone on plants at the four-leaf stage, which is the optimal stage for infecting pepper with geminiviruses using the biolistic procedure (Garzón-Tiznado et al., 1993). Inoculated plants were incubated at 24 to $32^{\circ} \mathrm{C}$ in a greenhouse (Godínez-Hernández et al., 2001). Plants that did not show typical symptoms $30 \mathrm{~d}$ postinoculation (9-13 leaf stage), were then inoculated by grafting with stem pieces of 'Sonora Anaheim' with both PHV and PepGMV, to avoid the presence of "escapes" during the biolistic inoculation (Godínez-Hernández et al., 2001). The scion was grafted $10 \mathrm{~cm}$ from the plant crown zone, with 6-8 and 3-5 leaves above and below the graph, respectively. The grafting method is not feasible in four-leaf stage plants because severe stem damage may occur and plants may die. Stem pieces of 'Sonora Anaheim' were verified for presence of PHV and PepGMV by PCR analysis with specific oligonucleotides to each virus (described below) (Fig. 1).

Evaluation of viral resistance and virus detection. After inoculation by either biolistic methods, grafting methods, or both, plants were incubated for 3 months in a

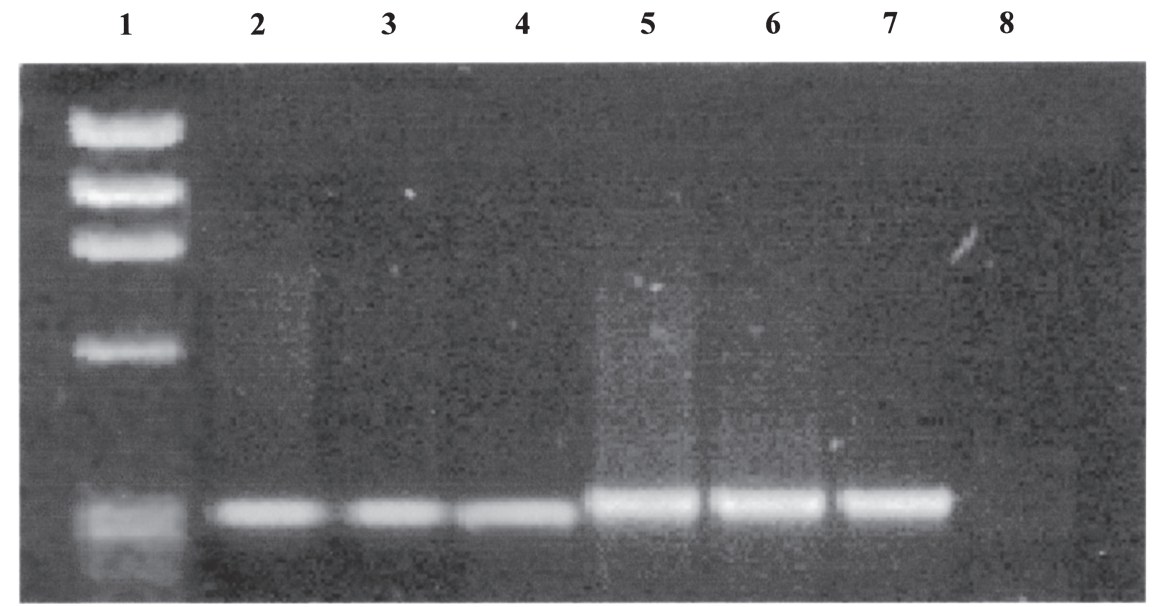

Fig. 1. Detection by PCR of HV and PepGMV DNA's in the scion used for grafting experiments. Lane $1=$ molecular weight marker; lanes 2-3 = amplification of PepGMV; lane 4=PepGMV positive control; lanes 5-6, amplifications of PHV; lane 7 = PHV positive control (350 bp); and lane $8=$ negative control.

greenhouse. Tissue samples from both lower (older) and upper (newly developed) leaves were randomly taken at 11-, 21-, 31-, 45-, 59-, and 90-d post-inoculation (dpi). Severity of pepper disease by geminiviruses was qualitatively measured using a scale reported elsewhere (Godínez-Hernández et al., 2001; Hernández-Verdugo, et al., 1998; TorresPacheco, 1997), where: 0 = asymptomatic; $1=$ slight crumpling on apical leaves and presence of yellow spots $(\approx 1 \mathrm{~mm}$ in diameter) when exposing leaves to sunlight; $2=$ presence of yellow spots in groups on apical leaves; 3 = groups of yellow spots coalesced forming a slight network on the base of apical leaves; $4=$ network clearly visible; $5=$ protuberances observable in the middle zone of apical leaves; $6=$ slight leaf curling; 7 $=$ severe leaf curling; $8=$ complete apical leaf distortion; and $9=$ leaf stunting. Plant DNA extractions from samples were carried out according to Dellaporta et al., (1983). Detection of PHV and PepGMV DNA was carried out using polymerase chain reaction (PCR) with specific oligonucleotides for each virus. For PHV detection, the oligonucleotides used were, 240 (5'GGCTTATTTGTA ATAAGAGAGGTGT3') and 241 (5'GAATT AAAGGTACATGGACCACTT3'), which amplify $350 \mathrm{bp}$ from the intergenic region of component A. For PepGMV detection, the oligonucleotides used were JM23 (5'TGG TGTAGGACTCCAGCAGAGTC3') and JM24 (5`TAGGCCCAC ACC TTG GTG ACC AAG 3') that amplify the intergenic region of component A (211 bp). PCR reactions contained the following components: 0.75 $\mu \mathrm{L}$ each deoxinucleotides $(2.5 \mathrm{~mm}), 2 \mu \mathrm{L}$ of oligonucleotides $\left(50 \mathrm{ng} \cdot \mu \mathrm{L}^{-1}\right), 0.5 \mu \mathrm{L}$ de Taq DNA polymerase $(6 \mathrm{U} / \mu \mathrm{L}), 1 \mu \mathrm{L}$ of plant DNA $\left(100 \mathrm{ng} \cdot \mu \mathrm{L}^{-1}\right)$ in a reaction volume of $50 \mu \mathrm{L}$. PCR conditions to amplify PHV were: $94^{\circ} \mathrm{C}$, $1 \mathrm{~min} ; 55^{\circ} \mathrm{C}, 1 \mathrm{~min}$ and $72{ }^{\circ} \mathrm{C}, 2 \mathrm{~min}$; and for PepGMV: $94{ }^{\circ} \mathrm{C}, 1 \mathrm{~min} ; 55^{\circ} \mathrm{C}, 2 \mathrm{~min}$ and $72{ }^{\circ} \mathrm{C}, 2 \mathrm{~min}$; in both cases for 35 cycles. PCR products were visualized on $1.5 \%$ agarose gels and densitometric values were obtained using a digital image system (1D Image Analysis Software, version 3.02; Kodak Digital System, Rochester, N.Y.).

Table 1. Disease reaction, collection location, inoculation method, and Capsicum species ofevaluated plants.

\begin{tabular}{|c|c|c|c|}
\hline $\begin{array}{l}\text { Disease reaction } \\
\text { (no. individuals }{ }^{z} \text { ) }\end{array}$ & $\begin{array}{l}\text { Collection } \\
\text { location }\end{array}$ & $\begin{array}{l}\text { Inoculation } \\
\text { method }\end{array}$ & Species \\
\hline \multicolumn{4}{|l|}{ Susceptible } \\
\hline 16 & Yucatán ${ }^{y}$ & Biolistic & C. chinense Jacq. \\
\hline 5 & Sinaloa & Biolistic & C. anпиит $\mathrm{L}$. \\
\hline 2 & Michoacán & Biolistic & C. аппиит $\mathrm{L}$. \\
\hline 1 & Tamaulipas & Biolistic & C. аппиит $\mathrm{L}$. \\
\hline \multicolumn{4}{|l|}{ Symptom delayed } \\
\hline 1 & Tamaulipas & Biolistic/Grafting & C. annuиm $\mathrm{L}$. \\
\hline 1 & Yucatán & Biolistic/Grafting & C. chinense Jacq. \\
\hline \multicolumn{4}{|c|}{ Symptom remission } \\
\hline 12 & Yucatán & Biolistic & C. chinense Jacq. \\
\hline 2 & Tamaulipas & Biolistic & C. anпиит $\mathrm{L}$. \\
\hline \multicolumn{4}{|l|}{ Asymptomatic } \\
\hline 4 & Tamaulipas & Biolistic/Grafting & C. annumm $\mathrm{L}$. \\
\hline 2 & Yucatán & Biolistic/Grafting & C. chinense Jacq. \\
\hline 2 & Sinaloa & Biolistic/Grafting & C. аппиит $\mathrm{L}$. \\
\hline
\end{tabular}

${ }^{\mathrm{z}} \mathrm{A}$ total of 48 individual pepper plants were evaluated. As a control, 20 pepper plants of 'Sonora Anaheim', were inoculated with both methods, resulting in $100 \%$ of plants with characteristic symptoms of the disease by geminiviruses (PHV plus PepGMV).

yThe accessions are identified as BG-3818 (Michoacán), BG-3819 (Sinaloa), BG3820 (Tamaulipas), and BG-3821 (Yucatán). 
Table 2. Mean of viral DNA levels, and severity of symptoms in pepper plants expressing 4 disease responses to geminiviral mixed infections with PHV and PepGMV.

\begin{tabular}{|c|c|c|c|c|c|c|}
\hline \multirow{3}{*}{$\begin{array}{l}\text { Disease } \\
\text { reaction }\end{array}$} & \multicolumn{4}{|c|}{ Mean $^{2}$ of DNA levels } & \multirow[b]{3}{*}{ Total ${ }^{y}$} & \multirow[b]{3}{*}{ Severity $^{\mathrm{x}}$} \\
\hline & \multicolumn{2}{|c|}{ Upper } & \multicolumn{2}{|c|}{ Lower } & & \\
\hline & PHV & PepGMV & $\overline{\mathrm{PHV}}$ & PepGMV & & \\
\hline Susceptible & $28.02 \mathrm{a}^{\mathrm{w}}$ & $13.31 \mathrm{a}$ & $7.79 \mathrm{a}$ & $15.44 \mathrm{a}$ & $26.04 \mathrm{a}$ & $2.36 \mathrm{a}$ \\
\hline Delay in symptoms & $5.69 \mathrm{ab}$ & $2.93 \mathrm{~b}$ & $2.17 \mathrm{~b}$ & $4.70 \mathrm{~b}$ & $7.38 \mathrm{~b}$ & $1.62 \mathrm{~b}$ \\
\hline Remission of symptoms & $5.91 \mathrm{ab}$ & $3.47 \mathrm{~b}$ & $3.77 \mathrm{~b}$ & $3.58 \mathrm{~b}$ & $9.57 \mathrm{~b}$ & $1.46 \mathrm{~b}$ \\
\hline Asymptomatic plants & $1.90 \mathrm{~b}$ & $1.33 \mathrm{~b}$ & $2.31 \mathrm{~b}$ & $2.64 \mathrm{~b}$ & $3.69 \mathrm{~b}$ & $1.0 \mathrm{c}$ \\
\hline
\end{tabular}

${ }^{2}$ Mean of six observations.

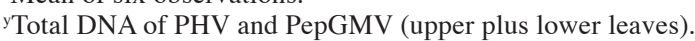

${ }^{x}$ Mean of six observations. Values are according to a scale reported by Torres-Pacheco et al. (1996). 0, asymptomatic; 1 , slight crumpling in apical leaves and presence of yellow spots $(\approx 1 \mathrm{~mm}$ in diameter $)$ when exposed to sun light; 2, presence of yellow spots in groups on apical leaves; 3 , groups of yellow spots coalesced forming a network on the base of apical leaves; 4 , network clearly visible; 5 , protuberances observable in the middle zone of apical leaves; 6 , slight leaf curling; 7 , severe leaf curling; 8 , complete apical leaf distortion; 9, leaf stunting.

"Values in each column followed by different letters (a, b, or c), indicates they are significantly different at $P<0.01$. The Tukey test was the method of mean separation used.

\section{a. Susceptible.}
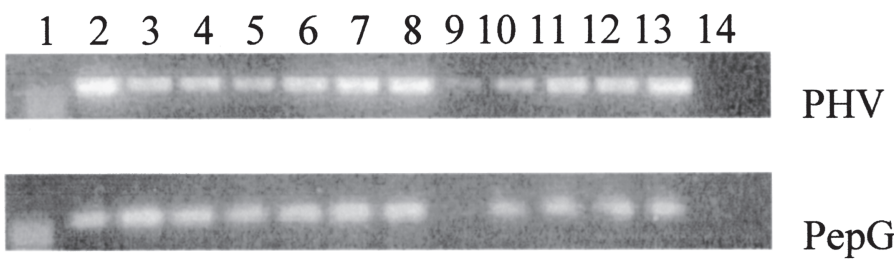

\section{PepGMV}

\section{b. Asymptomatic.}
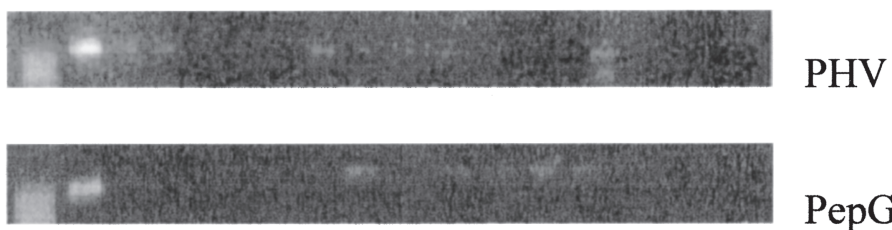

\section{PepGMV}

\section{c. Delay in Symptoms.}

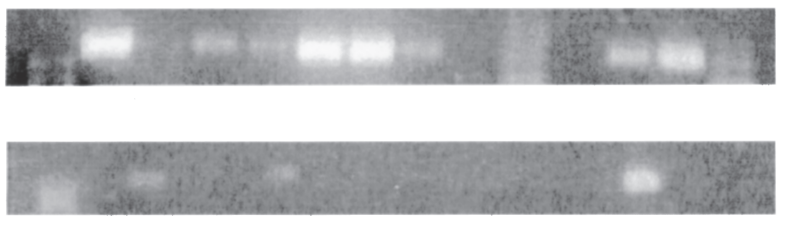

PHV

\section{PepGMV}

\section{d. Remission.}

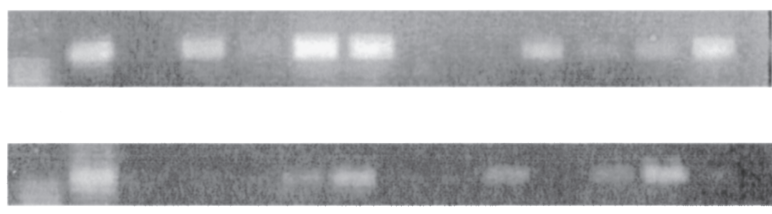

\section{PHV}

\section{PepGMV}

Fig. 2. Detection by PCR of PHV and PepGMV on upper and lower leaves of representative individuals of each phenotypical response. Panel $\mathrm{a}=$ susceptible; $\mathrm{b}=$ asymptomatic; $\mathrm{c}=$ delay in symptoms; and $\mathrm{d}=$ remission in symptoms. primers used in PCR detect specifically a fragment of the common region of each virus (350 bp) for PHV and $200 \mathrm{bp}$ for PepGMV, respectively). Lane $1=$ molecular weight marker; lanes 3-8 detection of upper leaves at 11,21, 31, 54, 59, and $92 \mathrm{dpi}$; and lanes 9-13 = detection off lower leaves at 11,21,31, 45, and 59 dpi. Lanes 2 and $14=$ positive and negative controls, respectively.
Statistical analysis. Analysis of variance and correlation among viral DNA levels in different interactions and severity of symptoms were carried out using SAS Proc GLM (SAS Institute, 1990). In order to optimize the analysis, all the data were transformed to square-root of $x+1$ ( $x=$ each value of densitometry).

\section{Results and Discussion}

After viral inoculation with both methods, 24 plants were resistant at different degrees to PHV-PepGMV infection. Eight of these plants were asymptomatic, no symptoms were observed on either the four initially inoculated leaves using the biolistic procedure (fourleaf stage) or on the newly developed leaves (after biolistic and grafting inoculation). These plants were: four from Tamaulipas (BG-3820), two from Yucatán (BG-3821), and two from Sinaloa (BG-3819) (Table 1). Fourteen of the plants showed symptoms remission. These plants were inoculated by the biolistic method and expressed symptoms on upper and lower leaves at 13-15 dpi, but a reduction in the severity of the symptoms was observed in the newly developed leaves (Table 1). The remaining two plants showed a delay in symptom appearance of $40 \mathrm{dpi}$. These plants were initially inoculated using biolistic and 30 d later by grafting and originated in Yucatán and Tamaulipas (Table 1). Fifty percent of the plants tested in this study were susceptible (Table 1). All of these plants were inoculated only by the biolistic procedure.

The relationship between viral DNAlevels of PHV and PepGMV, and severity of symptoms in pepper plants are shown in Table 2 . In regard to PHV, DNA levels in upper and lower leaves, were positively correlated to severity of symptoms $(r=0.70$ and 0.78 , respectively; $P<0.01)$. Statistical analysis suggested three groups for PHV DNA levels on upper leaves: group a = susceptible plants; $a b=$ plants with remission or delay in symptom appearance; and $b=$ asymptomatic plants (Table 2). However, two statistical groups were identified for PHV levels of lower leaves: a = susceptible; and $\mathrm{b}=$ remission, delayed in symptom appearance and asymptomatic plants (Table 2). Considering total PHV DNA levels (upper and lower leaves), three statistical groups were identified: $a=$ susceptible; $a b$ $=$ remission; and $\mathrm{b}=$ delayed in symptoms and asymptomatics (data not shown). As for upper and lower leaves, total PHV DNA levels correlated with severity of symptoms $(r=0.79, P<0.01)$.

For PepGMV DNA levels, two statistical groups were detected on both upper and lower leaves: $\mathrm{a}=$ susceptible individuals; and $\mathrm{b}=$ remission, delayed in symptom appearance and asymptomatic plants (Table 2). Correlation analysis indicated a positive relationship between severity of disease and PepGMV levels on upper and lower leaves $(r=0.68$ and 0.66, respectively; $P<0.01$ ). Total PepGMV levels showed two statistical groups: $\mathrm{a}=$ susceptible; and $\mathrm{b}=$ remission, delayed in symptoms appearance and asymptomatic plants (data not shown). Besides, in this case, 
Breeding, Cultivars, Rootstocks, \& Germplasm Resources

Table 3. DNA levels ${ }^{z}$ of both PHVy and PepGMV on upper leaves in representative individuals of mixed-infected pepper plants.

\begin{tabular}{|c|c|c|c|c|c|c|c|c|c|c|c|c|}
\hline \multirow{3}{*}{$\begin{array}{l}\text { Disease } \\
\text { reaction }\end{array}$} & \multicolumn{12}{|c|}{ Days post-inoculation } \\
\hline & \multicolumn{2}{|c|}{11} & \multicolumn{2}{|c|}{21} & \multicolumn{2}{|r|}{31} & \multicolumn{2}{|c|}{45} & \multicolumn{2}{|c|}{59} & \multicolumn{2}{|c|}{90} \\
\hline & PHV & PepGMV & PHV & PepGMV & $\overline{\mathrm{PHV}}$ & PepGMV & $\overline{\mathrm{PHV}}$ & PepGMV & $\overline{\mathrm{PHV}}$ & PepGMV & $\overline{\mathrm{PHV}}$ & PepGMV \\
\hline Susceptible & 206.4 & 381.2 & 202.4 & 125.8 & 47.5 & 66.9 & 571.6 & 123.9 & 309.5 & 222.7 & 290.9 & 215.2 \\
\hline Delay in symptoms & 10.2 & 7.3 & 15.9 & 13.9 & 13.4 & 0 & 91.1 & 7.7 & 83.3 & 14.1 & 16.1 & 7.9 \\
\hline Symptoms remission & 0 & 9.1 & 175.0 & 8.3 & 15.5 & 0 & 95.2 & 10.8 & 13.6 & 49.1 & 11.6 & 8.4 \\
\hline Asymptomatic plants & 0 & 0 & 12.9 & 0 & 0 & 0 & 0 & 0 & 0 & 0 & 12.9 & 7.9 \\
\hline
\end{tabular}

${ }^{2}$ Values are indicated in nanograms of DNA (determined by densitometry analysis) of an individual plant representative of the phenotypic behavior of the population in each phenotypic response.

${ }^{y}$ Total PHV values were significantly higher than those of PepGMV $(P<0.01)$ regardless the disease reaction of pepper plants.

Table 4. Severity ${ }^{\mathrm{z}}$ of disease in representative individuals of mixed-infected pepper plants.

\begin{tabular}{lllllll}
\hline Disease & \multicolumn{5}{c}{ Days postinoculation } \\
\cline { 2 - 7 } reaction & 11 & 21 & 31 & 45 & 59 & 90 \\
\hline Susceptible & 2 & 5 & 5 & 5 & 6 & 5 \\
Delay in symptoms & & & & & & \\
$\quad$ appearance & 0 & 0 & 0 & 3 & 3 & 2 \\
Symptoms remission & 0 & 3.5 & 2 & 2 & 2 & 1 \\
Asymptomatic & 0 & 0 & 0 & 0 & 0 & 0 \\
\hline
\end{tabular}

${ }^{2}$ Values are according to a scale reported by Torres-Pacheco et al. (1996). 0, asymptomatic; 1 , slight crumpling in apical leaves and presence of yellow spots $(\approx 1$ $\mathrm{mm}$ in diameter) when exposed to sun light; 2 , presence of yellow spots in groups on apical leaves; 3 , groups of yellow spots coalesced forming a network on the base of apical leaves; 4 , network clearly visible; 5 , protuberances observable in the middle zone of apical leaves; 6 , slight leaf curling; 7 , severe leaf curling; 8 , complete apical leaf distortion; and 9, leaf stunting.

a positive correlation was observed between viral DNA levels and severity of disease $(r$ $=0.83, P<0.01)$. Regardless of the interaction, for each virus, no significant difference was found between DNA levels on upper in comparison to lower leaves $(P<0.01$, data not shown).

Considering total viral DNA (PHV and PepGMV on upper and lower leaves), two statistical groups were identified: $\mathrm{a}=$ susceptible plants; and $\mathrm{b}=$ plants with delay in symptoms, remission and asymptomatic (Table 2). Correlation between total viral DNA levels and severity of disease was high $(r=0.84, P<$ $0.01)$. Three statistical groups were detected in regard to relationships between severity of disease and kind of syndrome in pepper plants to both geminiviruses: $\mathrm{a}=$ susceptible; $\mathrm{b}=$ remission and delay in symptoms; and $\mathrm{c}=$ asymptomatic individuals. As expected, a positive correlation was obtained between severity of disease and the type of syndrome ( $r=0.71, P<0.01)$. Thus, it was shown that in all cases, DNA levels of both PHV and PepGMV on either upper or lower leaves, were positively correlated to severity. This finding was expected based upon other reports that demonstrated that in single infections with PHV, viral DNA levels positively correlated with symptom severity (Hernández-Verdugo et al., 2001).

Regardless of the syndrome with pepper plants, comparison of total DNAlevels between both PHV and PepGMV on upper and lower leaves of pepper plants were significantly different, detecting two statistical groups: a $=$ PHV; and $\mathrm{b}=$ PepGMV at $P<0.01$ (Table 3 ). Thus, to compare DNA levels of PHV and PepGMV for the four type of syndromes expressed by the wild pepper accessions, DNA levels of each virus and severity of disease was analyzed on a representative individual of each kind of syndrome during $90 \mathrm{~d}$ (Fig. 2 , Tables 3 and 4). It is worth mentioning that data showed in Tables 3 and 4 are from the same representative individual plant of each syndrome. In order to simplify the analysis, only viral DNA levels on upper leaves were studied in this experiment. For the susceptible individual, DNA levels of both geminiviruses were high and similar from 11-90 dpi (Table 3), and severity of disease progressively increased (Table 4). In the plant with delay in symptom appearance, DNA levels of both viruses were low through $31 \mathrm{dpi}$, and severity of disease was null. Then at $45 \mathrm{dpi}$, a slight increase in DNA levels of PHV was observed and severity of disease was also increased (Tables 3 and 4). This severity increment appeared $15 \mathrm{~d}$ after grafting inoculation on this plant, suggesting that biolistic inoculation introduced both viruses within the plant. Although they were innocuous until grafting was done, then the plant became affected. This result suggests that the inoculation method is an important variable to be considered while testing for virus resistance in plants. Furthermore, for the plant with remission in symptoms, DNA levels of both geminiviruses were low at $11 \mathrm{dpi}$ and at 21 dpi. However, PHV levels increased and were correlated with a concomitant increase in symptom severity (Tables 3 and 4). There after, PHV DNAlevels decreased, and PepGMV remained low and severity of symptoms progressively diminished (Tables 3 and 4). Finally, in the case of the asymptomatic plants, DNA levels of both geminiviruses were low during the 90 $\mathrm{d}$ of incubation, and the severity of disease was null (Tables 3 and 4). The fact that PHV levels were significantly higher than those of PepGMV on either upper or lower leaves (Table 3 ), suggests that PHV is somehow more prone than PepGMV to infect these pepper plants. This suggestion is supported by the fact that in pepper plants, $\mathrm{PHV}$ is able to complement the movement of PepGMV component A, but this does not occur (or it occurs at an extremely low level) in the reciprocal combination (Torres-Pacheco, 1997). It was clear, that whatever the mechanism of resistance in the plants with no presence, remission or delay in symptoms, it appears to be affecting PHV in a lesser degree.

In a recent report on pepper plants resistant to PHV in single infections, it was demonstrated that the resistance mechanism did not affect viral replication, thus, it was concluded that the mechanism may have restricted viral movement (Godínez-Hernández et al., 2001). Thus, it is unlikely that replication of PHV and PepGMV is affected in some plants used in this study; then, a likely resistance mechanism to geminiviruses in the pepper plants evaluated in this work could somehow be affecting viral movement. Additionally, another explanation of the results should be considered. The problems in viral replication efficiency or translation of viral genes could be negatively affected by these plants and the resulting reduction in viral accumulation may provoke, indirectly, a reduced or delayed movement. Moreover, the fact that several plants displayed a delay in symptom appearance, also suggests that the movement of both PHV and PepGMV was affected. When the plant with delay in symptom appearance (Tables 3 and 4) was inoculated by biolistic, both PHV and PepGMV were innocuous (perhaps because cell to cell movement was affected). However, when that plant was grafted, characteristic PHV and PepGMV symptoms were observed, which suggests that resistance was broken in this plant by the direct viral entrance into vascular bundles by grafting inoculation. Several reports indicate that viral movement is frequently affected in plants displaying resistance to a virus (Fraser, 1990; Hull, 1991). It has been demonstrated that viral replication is possible in protoplasts of nonhost plants; moreover, tissues of symptomless plants, support virus multiplication in a single or few directly inoculated cells (Fraser, 1990; Paje-Manalo and Lommel, 1989). The interaction in which pepper plants showed a remission in symptomatology suggests that initially, viral movement and replication were adequate to infect the plants, but later, a resistance mechanism was probably induced, causing a reduction in viral DNA levels and symptom severity. Plants showing symptom remission may be expressing a type of RNA- 
mediated virus resistance or gene silencing in which a cellular, cytoplasmic activity is provoking a highly selected RNA elimination as demonstrated elsewhere (de Haan et al., 1992; Lindbo et al., 1993; Pang et al., 1993; Schiebel et al., 1998; van der Vlugtet al., 1992). Asymptomatic plants may be resistant at any one or combinations of the mechanisms mentioned. Experiments trying to characterize the resistance mechanism on the interactions found in this work are currently in progress in our laboratory. The individual resistant pepper plants identified in this work, may be useful candidates to study genetics and molecular biology of resistance to geminiviruses, and these individuals may serve as sources of resistance in pepper breeding programs.

\section{Literature Cited}

Burdon, J.J. and A.M. Jarosz. 1989. Wild relatives as sources of disease resistance, p. 280-296. In: A.H.D. Brown, O.H. Frankel, D.R. Marshall, and J.T. Williams (eds.). The use of plant genetic resources. Cambridge Univ. Press, Cambridge.

Bonilla-Ramírez, G.M., R.G. Guevara-González, J.A. Garzón-Tiznado, J.T. Ascencio-Ibañez, I. Torres-Pacheco, and R.F. Rivera-Bustamante. 1997. Analysis of the infectivity of monomeric clones of pepper huasteco virus. J. Gen. Virol. 78:947-951.

de Haan, P., J.J.L. Gielen, M. Prins, M.G. Wijkamp, A. van Schepen, D. Peter,M.Q.J.M. van Grievsen, and R.W. Goldbach. 1992. Characterization of RNA-mediated resistance to tomato spotted wilt virus, a negative-strand RNA virus. Bio/ technology 10:1133-1137.

Dellaporta, S.L; J. Wood, and J.B. Hicks. 1983. A plant DNA minipreparation: Version II. Plant Mol. Biol. Rpt. 1:19-21.

Food and Agriculture Organization. 1999. Agricultural Production: Primary crops. http: //apps.fao.org//lim500//Agri_db.pl

Fraser,R.S.S. 1990. The genetics of resistance to plant viruses. Annu. Rev. Phytopathol. 28:179-200.

Garzón-Tiznado, J.A., R.F. Rivera-Bustamante, L. Herrera-Estrella, F. Delgadillo-Sánchez, and O. Pozo-Campodónico. 1989. Estudio preliminar sobre el rizado amarillo del chile (Capsicum аппиит L.) en el sur de Tamaulipas. Un geminivirus. XII Congreso Nacional de la Sociedad Mexicana de Fitopatología. Edo. de México. p.16.

Garzón-Tiznado, J.A., I. Torres-Pacheco, J.T. Ascencio-Ibañez, L. Herrera-Estrella, and R.F. Rivera-Bustamante. 1993. Inoculation of peppers with infectious clones of a new geminivirus by a biolistic procedure. Phytopathology 53:514-521.
Godínez-Hernández, Y., J.L. Anaya-López, R. Díaz-Plaza, M. González-Chavira, R.F. Rivera-Bustamante, I. Torres-Pacheco, and R.G. Guevara-González. 2001. Characterization of resistance to pepper huasteco geminivirus in chili peppers (Capsicum chinense) from Yucatán, México. HortScience 36:139-142.

Hanley-Bowdoin, L., S.B. Settlage, B.M. Orozco, S Nagar, and D. Robertson. 1999. Geminiviruses: Models for plant replication, transcription, and cell regulation. Crit. Rev. Plant Sci. 18:71-106.

Harlan, J.R. 1976. Genetics resources in the wild relatives of crops. Crop Sci. 16:329-333.

Hernández-Verdugo, S., R.G. Guevara-González, R.F. Rivera-Bustamante, and K. Oyama. 1998. Los parientes silvestres del chile (Capsicum spp.) como recursos genéticos. Bol. Soc. Bot. México 62:171-181

Hernández-Verdugo, S., R.G. Guevara-González, R.F. Rivera-Bustamante, and K. Oyama. 2001. Screening wild plants of Capsicum annuит for resistance to pepper huasteco virus (PHV): Presence of viral DNA and differentiation among populations. Euphytica 122:31-36.

Hull, R. 1991. The movement of viruses in plants. Annu. Rev. Phytopathol. 27:213-240.

Kasrawi, M.A., M.A. Suwwan, and A. Mansour. 1988. Sources of resistance to tomato yellow leaf curl virus (TYLCV) in Lycopersicon species. Euphytica 37:61-64.

Lazarowitz, S.G. 1992. Geminiviruses: Genome structure and gene function. Crit. Rev. Plant Sci. 11:327-349.

Lindbo, J.A., L. Silva-Rosales, W. Proebsting, and W. G. Dougherty. 1993. Induction of a highly specific anti-viral state in transgenic plants: Implications for gene regulation and virus resistance. Plant Cell 5:1749-1759.

Loaiza-Figueroa, F., K. Ritland, J.A. Laborde-Cansino, and S.D. Tanksley. 1989. Patterns of genetic variation of the genus Capsicum (Solanaceae) in México. Plant System and Evol.165:159-188.

Paje-Manalo, L.L. and S.A. Lommel. 1989. Independent replication of red clover necrotic mosaic virus RNA-1 in electroporated hosts and nonhost Nicotiana species protoplasts. Phytopathology 79:457-461.

Pang, S.Z., J.L. Slightom, and D. Gonsalves. 1993. Different mechanisms protect transgenic tobacco against tomato spotted wilt and impatients necrotic spot tospoviruses. Bio/Technology 11: 819-824.

Pickersgill, B. 1984. Migration of chili peppers, Capsicum spp. in the Americas, p. 105-123. In: D. Stone (ed.). Papers of the Peabody Museum of Archeology and Ethnology. Harvard Univ. Press, Cambridge.

Pilowsky, M.A. and S. Cohen. 1990. Tolerance to tomato yellow leaf curl virus derived from Lycopersicon peruvianum. Plant Dis. 74:248-250.

Piven, N.M. and R. Uzcategui. 1995. Resistance to mosaic virus in species of Lycopersicon. Plant Dis. 79:590-594.

Polston, J.E, and P.K. Anderson. 1997. The emergence of whitefly-transmitted geminiviruses in tomato in the western hemisphere. Plant Dis. 81:1358-1369.

Pozo-Campodónico, O., H.S. Montes, and J.E Redondo. 1991. El chile (Capsicum spp.), p. 217-238. In: Sociedad Mexicana de Fitogenética, A.C. (eds.). Avances en el estudio de los recursos fitogenéticos de México.

SAS Institute.1990. SAS/STAT user's guide. Version 6. 4th ed. SAS Inst., Cary, N.C.

Schiebel, W., T. Pélissier, L. Riedel, S. Thalmeir, R. Schiebel, D. Kempe, F. Lottspeich, H. Sänger, and M. Wassenegger. 1998. Isolation of an RNAdirected RNA polymerase-specific cDNA clone from tomato. Plant Cell 10:2087-2110.

Stalker, H.T. 1980. Utilization of the wild species for crop improvement. Adv. Agron. 33:717-724.

Torres-Pacheco, I. 1997. Geminivirus involucrados en el rizado amarillo del chile: Interacciones entre PHV y TPV.Ph.D Diss. Centro de Investigación y de Estudios Avanzados del I.P.N, Unidad Irapuato, México.

Torres-Pacheco, I., J.A. Garzón-Tiznado, L. Herrera-Estrella, and R.F. Rivera-Bustamante. 1993. Complete nucleotide sequence of pepper huasteco virus: Analysis and comparison with bipartite geminiviruses. J. Gen. Virol. 74: 2225-2231.

Torres-Pacheco, I., J.A. Garzón-Tiznado, J.K. Brown, A. Becerra-Flora, and R.F. Rivera-Bustamante. 1996. Detection and distribution of geminiviruses in Mexico and Southern United States. Phytopathology 86:1186-1192.

van der Vlugt, R.A.A., R.K. Ruiter, R. Goldbach. 1992. Evidence for sense RNA-mediated protection to $\mathrm{PVY}^{\mathrm{N}}$ in tobacco leaves plants transformed with the viral coat protein cistron. Plant Mol. Biol. 20:631-639.

Vera-Aguado, M.G., R. Díaz-Plaza, M. GonzálezChavira, J.A. Garzón-Tiznado, R.F. RiveraBustamante, R.G. Guevara-González, and I. Torres-Pacheco. 1999. Detection of viruses in tomato (Lycopersicon esculentum), pepper (Capsicum annuum), and weeds in different environments in México: Advances. VIII Congreso Nacional de Horticultura, Manzanillo, Colima, México.

Williams, P.H. 1988. Screening for resistance to disease, p. 335-364. In: A.H.D. Brown, O.H Frankel, D.R. Marshal, and J.T. Williams (eds.). The use of plant genetic resources. Cambridge Univ. Press, Cambridge.

Zakay, Y., N. Navot, M, Zeidan, N. Kedar, H, Rabinowitch, H. Czosnek, and D, Zamir. 1991. Screening Lycopersicon accessions for resistance to tomato yellow leaf curl virus: Presence of viral DNA and symptoms development. Plant Dis. 75: 279-281. 